\title{
TYPE 2 DIABETES MELLITUS ON TRIGLYCERIDE LEVELS AND BLOOD PRESSURE
}

\author{
Wirawan Anggorotomo ${ }^{1}$, Tessa Sjahriani ${ }^{2}$, Masroni ${ }^{3}$ \\ 1Medical Doctor at Pertamina Bintang Amin Hospital, Indonesia. Email: Senandung.bius@gmail.com \\ 2Lecturer in Faculty of Medicine, Malahayati University, Bandar Lampung, Indonesia. \\ Email: tessasah@gmail.com \\ ${ }^{3}$ Lecturer in Nursing Study Program, Institute of Health Sciences (STIKes) Banyuwangi-East Java, Indonesia. \\ Email: masroni86@gmail.com
}

\begin{abstract}
Background: Diabetes Mellitus (DM) is a group of metabolic diseases characterized by an abnormality of insulin secretion, insulin work, or both. DM cases in Indonesia as many as 8,5 million cases in 2013. Prevalence based on diagnosis or symptoms according to the health departement of 2,1\%.

Purpose: To know the correlation of type 2 diabetes mellitus on triglyceride levels and blood pressure

Methods: This study used secondary data derived from the medical record status of patients with diabetes mellitus. The method used is analytic observational with cross sectional approach. Sampling technique using purposive sampling. The population of this study is the diabetes mellitus type 2 in 2017 as many as 151. Sample of 109 respondents. Data analyzed by univariate and bivariate using Chi Square analysis.

Results: The frequency of respondent characteristic on female gender as much $57,8 \%$, based on age group $>45$ old counted $58,7 \%$. Blood pressure frequency distribution found hypertension as much $63,3 \%$. High frequency distribution of triglyceride levels is $67,9 \%$. The Chi Square analysis result there is a significant correlation of type 2 diabetes mellitus on triglyceride levels and blood pressure with Odds Ratio 6,865 with $p$-value of 0,009 .
\end{abstract}

\section{Keywords: Type 2 Diabetes Mellitus, blood pressure, Triglyceride.}

\section{INTRODUCTION}

Diabetes Mellitus (DM) is a group of metabolic diseases characterized by an abnormality of insulin secretion, insulin work, or both (Sudoyo, Setiyohadi, Alwi, Simadibrata, \& Setiati, 2006; Purnamasari, 2014). DM pathologic was related with less glucose intake of the body. DM patients have had lipid abnormality, the increase of lipid metabolism can cause abnormal lipid metabolism such as hypercholesterol and hypertrygliseride which cause aterosclerosis and decrease of protein in the body (Hall \& Guyton, 2015). WHO predicted the increase number of the DM patients in Indonesia in 2030 is 21,3 millions from 8,4 millions in the year 2000. While in 2009 is 7 millions increasing to 12 millions in the year 2030 (Perhimpunan Rumah Sakit Seluruh Indonesia, 2011). Indonesia has now shows the 4th rank of the greatest number of DM patients after US, China and India. Central Bureau of Statistics (CBS) shows the number of DM patients in Indonesia in 2030 is 13,7 millions, based on population growth in year 2030 there were 20,1 millions patients (14,7\% urban and 7,25 rural) (Perhimpunan Rumah Sakit Seluruh Indonesia, 2011).

DM prevalence based on diagnosedis 1,5\% and $0,4 \%$, based on symptoms is $2,1 \%$. Hypertension prevalence in Indonesia in the age
18 and above based on diagnosed or is $9,4 \%$, based on drinking medicine (without diagnose) is $9,5 \%$. There were $0,1 \%$ population have been drinking medicine (without diagnose). Hypertension prevalence based measurement in the age 18 and above is $25,8 \%$. So the coverage of medical staff were only $36,8 \%$ while $62,3 \%$ cases were under diagnose. The pravalence of DM, hypertyroid, and hipertension in women tends to be higher than men (Kementrian Kesehatan Republik Indonesia, 2013).

From the survey in RSUD. Dr. H. Abdoel Moeloek, Lampung province the amount of DM outpatients was occupy by the rank of 3 from 10 most disease. Based on data there were 6279 visited in year 2010, 5744 visited in 2011, 4248 visited in 2012, 6972 visited in 2013, and 581 visited on January-August 2014 (Amtiria, 2016). In Pertamina Bintang Amin Hospital, Lampung province there were 151 patients in year 2017; for the age 45 years old and less there were 24 patients, age 45-64 years old were 106 patients, age 65 years old and above were 21 patients. In year 2016 there were 134 DM type 2 patients (RSPBA, 2017). DM patients have had lipid abnormality, including the increase level of tryglyseride(caused by the increase of VLDL and lipoprotein remnant), increase level of LDL and decrease level of HDL. Diabetes hypertension 
were two of the risk factors which can cause aterosclerosis and the complication, including heart attack and stroke which were related to dyslipidemia (Siringoringo, 2015).

From Rahayu, Utomo, \& Setiawan. (2012) about the correlation between hypertension and diabetes from 38 respondents without hypertension there were 10 respondents $(26,3 \%)$ with $\mathrm{DM}$, and from 31 respondents with hypertension there were 10 respondents $(32,3 \%)$ with DM (Rahayu, Utomo, \& Setiawan, 2012). The level of tryglyseride on DM tipe 2 patients with hypertension was obtained $237,00 \pm 252,91$ and on DM tipe 2 patients without hypertension was $166,40 \pm 116,57$ (Wijaya, 2010).
Based on that background I was interested to do study about "The correlation of type 2 diabetes mellitus on triglyceride levels and blood pressure"

\section{RESEARCH METHODS}

This study used secondary data derived from the medical record status of patients with diabetes mellitus. The method used is analytic observational with cross sectional approach. Sampling technique using purposive sampling. The population of this study is the diabetes mellitus type 2 in 2017 as many as 151. Sample of 109 respondents (measurement using Slovin). Data analyzed by univariate and bivariate using Chi Square analysis.

\section{RESEARCH RESULTS \\ Univariate Analysis}

Table 1. Frequency Distribution of Respondent Characteristics ( $N=109)$

\begin{tabular}{lll}
\hline \multirow{2}{*}{ Characterization } & \multicolumn{2}{l}{ Total } \\
\cline { 2 - 3 } & $\mathrm{n}$ & $\%$ \\
\hline Sex & 46 & 42,2 \\
$\quad$ Men & 63 & 57,8 \\
$\quad$ Women & & \\
Age & 45 & 41,3 \\
$\quad \leq 45$ years old & 64 & 58,7 \\
$\quad>45$ years old & 64 & \\
\hline
\end{tabular}

Based on table 1. the respondents were mostly women (63/57,8\%), respondents, and the age was mostly 45 years old and above $(64 / 58,7 \%)$ respondents.

Table 2. Frequency Distribution of Respondent on blood pressure ( $N=109)$

\begin{tabular}{llll}
\hline Variable & & $\mathrm{n}$ & $\%$ \\
\hline \multirow{2}{*}{ Blood Pressure } & Normal & 40 & 36,7 \\
& Hypertension & 69 & 63,3 \\
\hline
\end{tabular}

The most DM type 2 patients were having hypertension (69/63,3\%) respondents.

Table 3. Frequency Distribution of Respondent on tryglyseride levels ( $N=109)$

\begin{tabular}{llll}
\hline Variable & & $\mathrm{n}$ & $\%$ \\
\hline \multirow{2}{*}{ Tryglyseride } & Normal & 35 & 32,1 \\
& High & 74 & 67,9 \\
\hline
\end{tabular}

The most type $2 \mathrm{DM}$ were having high of tryglyseride level $(74 / 67,9 \%)$ respondents.

\footnotetext{
Wirawan Anggorotomo' Medical Doctor at Pertamina Bintang Amin Hospital, Indonesia.

Email: Senandung.bius@gmail.com

Tessa Sjahriani ${ }^{2}$ Lecturer in Faculty of Medicine, Malahayati University, Bandar Lampung, Indonesia.

Email: tessasah@gmail.com

Masroni ${ }^{3}$ Lecturer in Nursing Study Program, Institute of Health Sciences (STIKES) Banyuwangi-East Java, Indonesia.

Email: masroni86@gmail.com
} 
Malahayati International Journal of Nursing and Health Science, Volume 01, No.1, March 2018: 11-16 TYPE 2 DIABETES MELLITUS ON TRIGLYCERIDE LEVELS AND BLOOD PRESSURE

\section{Byvariate Analysis}

Tabel 4. The Correlation of type 2 diabetes mellitus on triglyceride levels and blood pressure $(\mathrm{N}=109)$

\begin{tabular}{|c|c|c|c|c|c|c|c|c|c|}
\hline \multirow{2}{*}{\multicolumn{2}{|c|}{ Type 2 Diabetes Mellitus }} & \multicolumn{2}{|c|}{$\begin{array}{l}\text { Tryglyseride } \\
\text { Normal }\end{array}$} & \multicolumn{2}{|c|}{ High } & \multicolumn{2}{|c|}{ Total } & \multirow[t]{2}{*}{$p$-value } & \multirow[t]{2}{*}{ OR (CI 95\% ) } \\
\hline & & $\mathrm{n}$ & $\%$ & $\mathrm{n}$ & $\%$ & $\mathrm{~N}$ & $\%$ & & \\
\hline \multirow{2}{*}{$\begin{array}{l}\text { Blood } \\
\text { Pressure }\end{array}$} & Normal & 19 & $47,5 \%$ & 21 & $52,5 \%$ & 40 & $100 \%$ & & \\
\hline & Hypertension & 16 & $23,2 \%$ & 53 & $76,8 \%$ & 69 & $100 \%$ & 0,009 & $6,865(1,300-6,909)$ \\
\hline Total & & 35 & $32,1 \%$ & 74 & $67,9 \%$ & 109 & $100 \%$ & & \\
\hline
\end{tabular}

Table 4. shows that from 40 respondents was obtained 19 respondents $(47,5 \%)$ with normal blood pressure and normal level of tryglyseride and 21 respondents $(52,5 \%)$ with normal blood pressure and high level of tryglyseride, while from 69 respondentswas obtained 16 respondents $(23,2 \%)$ with hypertension and normal level of tryglyseride, and 53 respondents $(76,8 \%)$ with hypertensionand high level of tryglyseride, with $\mathrm{p}$ value 0,009 , Odd Ratio (OR) 6,865 , so Ho was rejected, and the conclusion is there is a correlation between diabetes mellitus type 2 patients with hypertension and non hypertension with triglyceride levels. With OR 6,865 which means Type 2 Diabetes Mellitus with hypertension were having 5,6 times bigger to increase their level of tryglyseride.

\section{DISCUSSION}

\section{Distribution of Respondent Characteristics}

Most respondents were women (63 respondents $/ 57,8 \%$ ), women were having higher risc of diabetes mellitus, it was inline with Trisnawati, \& Setyorogo, (2013) that the prevalence of DM Type 2 in women were higher than men, because physically womenwere having chances of higher Body Mass Index(BMI). Irwan (2010) shows that women have higher risc of diabetes, that caused by premenstrual syndrome and postmenopouse that makes lipid distribution was easy to accumulated by that hormonal process.

Based on the age most respondents were 45 years old and above (64 respondents/58,7\%), which means people with the age of 45 years old and above were having higher risk of diabetes mellitus. It was in line with the study of Trisnawati
(2013) that under 45 years old age group were having lower risk of diabetes mellitus. Sujaya (2008) shows that diabetes mellitus most occurs in $45-52$ years old age group $(47,5 \%)$. and aging also can cause the decrease of pancreas $\beta$ cell ability to produce insulin. Based on Novian (2013) most hypertension patients are above 46 years old, more older the age was physiologic changes in the body could happened such as the thickness of the artery wall caused by colagen stacks of the muscle layer, so the vascular would become narrow and rigid starting from the age 45 and then the peripheral resistance and sympathetic activity will increase, baroreceptor, renal blood circulation and glomerural filtration rate will decrease (Kumar, Abbas, \& Fausto, 2010).

The Correlation of type 2 diabetes mellitus on triglyceride levels and blood pressure

Based on the result of study the most respondents were hypertension (63 respondents $/ 63,3 \%$ ), there were having higher risc of diabetes melitus, with OR 6,85 times bigger compared to respondents without hypertension and shows that respondents with hypertension were having 1,5 times bigger risc of diabetes mellitus compared to respondents without hypertension and shows significant correlation between blood pressure and diabetes mellitus (Sujaya, 2008; Trisnawati, \& Setyorogo, 2013).

It was inline with the study of Mutmainah (2013) that shows hypertension were the main risc factor of DM. The correlation with DM type 2 werecomplex, hypertension can make insulin resistant, where as insulin can increase glucose intake on many cells and arrange carbohidratemetabolism. So ifinsulin resistant in

Wirawan Anggorotomo' Medical Doctor at Pertamina Bintang Amin Hospital, Indonesia.

Email: Senandung.bius@gmail.com

Tessa Sjahriani ${ }^{2}$ Lecturer in Faculty of Medicine, Malahayati University, Bandar Lampung, Indonesia.

Email: tessasah@gmail.com

Masroni ${ }^{3}$ Lecturer in Nursing Study Program, Institute of Health Sciences (STIKES) Banyuwangi-East Java, Indonesia.

Email: masroni86@gmail.com 
cellsoccured, the level of glucose blood level will cause disturbance (Guyton, 2012). Hypertension which stimultanously happened with diabetes mellitus was correlated with the coagulation abnormality and lipid disturbance. Insulin resistant insulin will increase a-adregenik andenzyme deficiency (lipoprotein lipase). These will cause lipid abnormalityeither as qualityincluding hyperlipidemia (the increase level of total kolesterol plasma, tryglyserida, and LDL), hipokolesterolemia HDL, the changes of LDL composition and increasing risc of oxidation (Wijaya, 2010).

Results of study shows that most tryglyserida level were high in 78 respondents $(67,9 \%)$, shows that most of the samples were having bad lipid profile, high level of tryglyserida were 47,2\% (Simbar, Pandelaki, \& Wongkar, 2015). It was inline with Wijaya (2010) that lipoprotein abnormalityin diabetes mellitus tipe 2 patients covered with hypertryglyserideand decrease of HDL plasma level, can also be founded LDL changes to smaller density to become aterogonik. Diabetes mellitus tipe 2 patients were also experiencing higher level of VLDL production.

Based on byvariate analysisthe correlation between Diabetes Melitus type 2 with hypertension and without hypertension and tryglyseride level from 40 respondents 19 respondents $(47,5 \%)$ withnormal blood pressure and normal level of tryglyserida, 21 respondents (52,5\%) withnormal blood pressure and high level of tryglyserida, meanwhilefrom 69 respondents 16 respondents $(23,2 \%)$ with hypertension and normal level of tryglyserida, 53 respondents $(76,8 \%)$ with hypertension and high level of tryglyseride. $p$ value of 0,009 and OR 6,865, so Ho was rejected, and the conclusion is there is a correlation between diabetes mellitus type 2 patients with hypertension and non hypertension with triglyceride levels. With OR 6,865 which means Diabetes Mellitus type 2 patients with hypertensionwere having 5,6 times bigger to increase their level of tryglyseride.

Research results by cross tabulation analysis was OR 2,00 and $p$-value 0,190 shows that patients with hypertension history were having 2 times higher risc of DM type 2 compared to patients without hypertension history even the statistical result were not significant Wicaksono (2011). Wijaya (2010) shows the mean level of tryglyserida in diabetes mellitus type 2 patients with hypertension was $237,00 \pm 252,91 \mathrm{mg} / \mathrm{dL}$, meanwhile the mean level of tryglyseridein diabetes mellitus type 2 patients without hypertension was $166,40 \pm 116,57 \mathrm{mg} / \mathrm{dL}$. The typical dyslipidemia in metabolic syndrome signed as increase level of tryglyserida and decrease level of HDL. Decrease level of HDL caused by the increase level of tryglyserida so than tryglyserida to HDL transfers occured. Despite of, in insulin resistant subjects, normal tryglyseride concentration and decrease level of HDL can be occured.

Diabetes and hypertension were both related. The changes of endothel function on diabetes mellitus had been proved by invivo nor invitro to decrease the production of antitrombolytic and vasodilatation such as nitrogen okside (NO), prostacicline, ADPase, trombomodulin, sulfas heparine and plasminogen activator, so that hypertension incidences can occured higher in diabetes mellitus. The increase was related to the increase of patients age and how long the diabetes melitus had been occured. Approximately 30-60\% diabetes mellitus patients have related with hypertension (Danuyanti, 2014).

Had been founded in DM type 2 that there were glucose metabolism disturbance caused by two main factors; insulin secretion adequacy (insulin deficiency) and less sensitive insulin (insulin resistance), beside the environment. The disease was progresive and tend to correlated with lipid nor protein metabolism disturbance. Higher level of blood glucose caused by lack of utilization that can cause lipid abnormality. Higher blood glucose (glucotoxicity) followed by dyslipidemia (lipotoxicity) were responsible of the tissue damagein direct nor stress oxidative and glikolisis spread (Manaf, 2014).

\section{CONCLUSION}

The distribution of Respondent Characteristics were mostly women $(63 / 57,8 \%)$ respondents, and the age was mostly 45 years old and above $(64 / 58,7 \%)$ respondents, hypertension $(69 / 63,3 \%)$ respondents and level of tryglyseride was high (74/67,9\%) respondents).

There is significant correlation of type 2 diabetes mellitus on triglyceride levels and blood

Wirawan Anggorotomo' Medical Doctor at Pertamina Bintang Amin Hospital, Indonesia.

Email: Senandung.bius@gmail.com

Tessa Sjahriani ${ }^{2}$ Lecturer in Faculty of Medicine, Malahayati University, Bandar Lampung, Indonesia.

Email: tessasah@gmail.com

Masroni ${ }^{3}$ Lecturer in Nursing Study Program, Institute of Health Sciences (STIKES) Banyuwangi-East Java, Indonesia.

Email: masroni86@gmail.com 
pressure with Odds Ratio 6,865 with $p$-value of 0,009 .

\section{SUGGESTIONS}

To women especially age 45 years old and above with type 2 diabetes mellitus to stay maintain healthy life to avoid hypertension, increase of tryglyseride level and take a routine control of lipid profile at the hospital.

\section{REFERENCES}

Amtiria, H. R. (2016). Hubungan pola makan dengan kadar gula darah pasien diabetes melitus tipe II di poli penyakit dalam RSUD DR. H. Abdul Moeloek Provinsi Lampung tahun 2015.

Danuyanti, I. G. A. N., Kristinawati, E., \& Resnhaleksmana, E. (2018). Hubungan Kadar Nitrit Oksida (NO) Dalam Darah Terhadap Resiko Kejadian Diabetes Mellitus Tipe 2 Dengan Hipertensi di RSUP NTB. Jurnal Kesehatan Prima, 8(1), 1207-1215.

Hall, G., \& Guyton, A. C. (2015). Buku ajar fisiologi kedokteran. Setiawan, I., penerjemah. Terjemahan dari: Textbook of medical physiology Jakarta: Penerbit Buku Kedokteran EGC.

Kementrian Kesehatan Republik Indonesia, (2013). Riset kesehatan dasar (Riskesdas) 2013. Jakarta: Badan Penelitian dan Pengembangan Kesehatan.

Kumar, V., Abbas, A. K., \& Fausto, N. (2010). Hypertensive vascular disease. Pathologic Basis of Disease, 10th ed. WB Saunders, 525530.

Manaf, A. (2014). Insulin: Mekanisme sekresi dan aspek metabolisme. Dalam: Buku ajar ilmu penyakit dalam jilid III edisi, 4, 1868-69.
Mutmainah, I. (2013). Hubungan Kadar Gula Darah Dengan Hipertensi Pada Pasien Diabetes Melitus Tipe 2 Di Rumah Sakit Umum Daerah Karanganyar (Doctoral dissertation, Universitas Muhammadiyah Surakarta).

Novian, A. (2013). Faktor yang Berhubungan dengan Kepatuhan Diit Pasien Hipertensi (Studi Pada Pasien Rawat Jalan di Rumah Sakit Islam Sultan Agung Semarang Tahun 2013) (Doctoral dissertation, Universitas Negeri Semarang).

Perhimpunan Rumah Sakit Seluruh Indonesia. (2011). Republik Indonesia Rangking Keempat Jumlah Penderita Diabetes Melitus Terbanyak Dunia. Cited on January 18 2018, dari http://www.pdpersi.co.id/kegiatan/ppidasar0416 .pdf

Purnamasari, D. (2014). Diagnosis dan klasifikasi diabetes melitus. Sudoyo, Aru W., Bambang Setyohadi, Idrus Alwi, Marcellus Simadibrata, Siti Setiati. Buku Ajar Ilmu Penyakit Dalam Jilid, $5,1880-1883$

Rahayu, P., Utomo, M., \& Setiawan, M. R. (2012). Hubungan Antara Faktor Karakteristik, Hipertensi dan Obesitas dengan Kejadian Diabetes Mellitus di Rumah Sakit Umum Daerah Dr. H. Soewondo Kendal. Jurnal Kedokteran Muhammadiyah, 1(2).

Simbar, M., Pandelaki, K., \& Wongkar, M. C. P. (2015). Hubungan Lingkar Pinggang dengan Profil Lipid pada Pasien Diabetes Melitus Tipe 2. e-CliniC, 3(1).

Siringoringo, Y. P. R. (2015). Perbedaan Kadar Trigliserida Pada Penderita Diabetes Melitus Tipe 2 Dengan Hipertensi Dan Tanpa Hipertensi Di RSUD Moewardi (Doctoral dissertation, Universitas Muhammadiyah Surakarta).

\footnotetext{
Wirawan Anggorotomo' Medical Doctor at Pertamina Bintang Amin Hospital, Indonesia. Email: Senandung.bius@gmail.com

Tessa Sjahriani ${ }^{2}$ Lecturer in Faculty of Medicine, Malahayati University, Bandar Lampung, Indonesia. Email: tessasah@gmail.com

Masroni ${ }^{3}$ Lecturer in Nursing Study Program, Institute of Health Sciences (STIKES) Banyuwangi-East Java, Indonesia. Email: masroni86@gmail.com
} 
Malahayati International Journal of Nursing and Health Science, Volume 01, No.1, March 2018: 11-16 TYPE 2 DIABETES MELLITUS ON TRIGLYCERIDE LEVELS AND BLOOD PRESSURE

Sudoyo, A. W., Setiyohadi, B., Alwi, I., Simadibrata, M., \& Setiati, S. (2006). Buku ajar ilmu penyakit dalam. Jakarta: FKUI, 400-411.

Sujaya, I. N. (2008). Pola konsumsi makanan tradisional Bali sebagai faktor risiko kejadian diabetes melitus tipe 2 di Kabupaten Tabanan (Doctoral dissertation, Universitas Gadjah Mada).

Trisnawati, S. K., \& Setyorogo, S. (2013). Faktor risiko Kejadian diabetes melitus tipe II di puskesmas kecamatan cengkareng Jakarta Barat Tahun 2012. Jurnal IImiah Kesehatan, 5(1), 6-11.
Wicaksono, R. P. (2011). Faktor-Faktor Yang Berhubungan Dengan Kejadian Diabetes Melitus Tipe 2 (Studi Kasus di Poliklinik Penyakit Dalam Rumah Sakit Dr. Kariadi (Doctoral dissertation, Faculty of Medicine).

Wijaya, A, A,. (2010). Perbedaan Profil Lipid Antara Pasien Diabetes Melitus Tipe 2 Dengan Hipertensi dan Tanpa Hipertensi. Karya IImiah S1 Kedokteran Universitas Sebelas Maret Surakarta, Surakarta.

Wirawan Anggorotomo' Medical Doctor at Pertamina Bintang Amin Hospital, Indonesia.

Email: Senandung.bius@gmail.com

Tessa Sjahriani ${ }^{2}$ Lecturer in Faculty of Medicine, Malahayati University, Bandar Lampung, Indonesia.

Email: tessasah@gmail.com

Masroni ${ }^{3}$ Lecturer in Nursing Study Program, Institute of Health Sciences (STIKES) Banyuwangi-East Java, Indonesia. Email: masroni86@gmail.com 